\title{
Place of the Woman in Indian Society: A Brief Review
}

\author{
Dr. Tukaram S. Sawant, \\ Tuljaram Chaturchand College of Arts, Science and Commerce, Baramati, Tal. Baramati, Dist. Pune, \\ Baramati-41310 2 (Maharashtra).
}

\begin{abstract}
Indian society belongs to the man since time immemorial. The woman has been given a secondary and inferior position in her family and society. She has been facing injustice, suppression, oppression, subjugation and exploitation in a male-dominated Indian society. In spite of being educated, she has been looked down upon with contempt. She has been reduced to the status of a plaything and a machine, a lifeless object used to fulfil men's sexual desire. She has been treated as a commodity to be used, controlled and disposed of by the male members of society. She, a meek and obedient member of a male-dominated society, a puppet that follows five paces behind her man, an inanimate object suffering on account of prejudice, orthodox conventions and traditions, is expected to be silent, tolerant and patient, and yet gentle and gracious, caring and loving, kind and considerate right from the ancient days. Though, like a man, she is born free, she is caught in chains in one way or the other. She is miles away from freedom from male-domination deeply rooted in a male-centric and patriarchal society with its conventional beliefs, superstitions, values and norms. The place and status equal to man need to be given to her in various fields of life. She is stronger and bolder than man in many respects. The woman occupies an important position as a wife, a mother, a daughter, a sister, and most importantly, as a human being in all human relationships. However, man-woman relationship is marred by the evils such as maleego, male-domination and gender-discrimination which seek to marginalize the role of a woman in Indian patriarchy. The present article is an attempt to review the place, position and status of an Indian woman in her family and society.
\end{abstract}

Key words: ardhangini, autonomous, dehumanization, gender-discrimination, orthodox patriarchy, reproduction.

The world belongs to the man since the beginning of civilization. It is unfortunate that men and women are not treated equally. Men are, after all, men while women are merely women. Women, being women, are not allowed to share the world in equality with men. It is not necessary for the man to define himself as an individual of a particular sex. However, the woman is required to define herself as a woman. She is not regarded as a free and independent individual. She has no existence apart from her male-counter-part. In this regard, Simone de Beauvoir writes: "Thus humanity is male and man defines woman not in herself but as relative to him; she is not regarded as an autonomous being". (Beauvoir 16). She further writes: "Man can think of himself without woman. She can not think of herself without man". (Beauvoir 25). She is simply what a man sees, defines and decrees. She is just what a man wants her to be. She is defined and understood only with reference to a man. She is incidental and inessential as opposed to her male counterpart who is essential. She finds herself living in the world of men in which the woman is assigned a secondary and inferior role. Beauvoir has rightly raised some fundamental questions related to women caught in the trap of patriarchy. The questions are: "How can a human being in woman's situation attain fulfillment? What roads are open to her? Which are blocked? How can independence be recovered in a state of dependency? What circumstances limit woman's liberty and how can they be overcome?" (Beauvoir 29). The writers, thinkers, philosophers and social reformers have been striving to answer these questions, but their efforts are in vain.

Kierkegaard, in Stages on the Road of Life, says: "To be a woman is something strange, so confused, so complicated, that no one predicate comes near expressing it and that the multiple predicates that one would like to use are so contradictory that only a woman could put up with it". (Kierkegaard 175). Man is always delighted by the very complexity and strangeness of her nature. She is what is given to man for his satisfaction. She is all that man desires and all that he does not attain all by himself. It is only through her that a man satisfies himself. She, too a large extent, appears to the male a sexual being. A woman, being close to man and totally dominated by him, follows him with his ideas and values blindly and mechanically. She accepts him as her destiny. She forgets her 'self' and 'identity'. She is deprived of liberty, or rather; she herself chooses to reject liberty. She is exploited and oppressed in each and every form. The subjugation and exploitation of the woman continues across class and caste. She is treated as a commodity, a property, and as a possession. Her life has been a story of treachery, oppression, sorrows and sufferings. She has been suffering under the oppressive mechanism of a closed society. She, to a large extent, is in a state of subjection. 
The woman, who is exploited and dehumanized by the institutionalized mechanism of prescriptive behaviour in the form of patriarchy, finds herself in an inevitable state of affairs. The process of dehumanization is accomplished by what the Latin American writer, Paulo Frier, calls 'prescription' - a basic element of the relationship between the oppressor and the oppressed. "Every prescription", he writes "represents the imposition of one man's choice upon another, transforming the consciousness of the man prescribed to into one that conforms to prescriber's consciousness. Thus, the behaviour of the oppressed is a prescribed behaviour following as it does the guidelines of the oppressor". (Paulo 23). Jessica Benjamin observers: "The anchoring of this structure so deep in the psyche is what gives domination its appearance of inevitability, makes it seem that a relationship in which both participants are subjects - both empowered and mutually respectful - is impossible". (Benjamin 85-86).

The psychologists and sociologists argue that there is a natural distinction between men and women. The basic difference lies in the fact that men are naturally polygamous, women are not. When a woman's desire for a loving mate, for home and for motherhood is satisfied, she doesn't need anything more in her life. Men, on the other hand, do not share these feelings and continue to seek variety in conquest. The woman is totally controlled and dominated by the males. She is expected to submit herself obediently and passively to the authority of a man. Simone de Beauvoir writes: "History has shown us that men have always kept in their hands all concrete powers; since the earlier days of the patriarchate they have thought best to keep woman in a state of dependence". (Beauvoir 171). She has been reduced to the status of a plaything and a machine, a lifeless object used only to fulfil a man's sexual desire. Man always wants her to be the object, to be the means of enjoyment. According to Jessica Benjamin, the male-ego and dominance is the key note in the analysis of man-woman relationship where the male attributes are associated with the mental thought and positive activity while the woman is regarded as a passive creature that is forced to respect the male sexual drive for the subsequent reproduction of the human species. (Figes 125). She opines that she has been assigned the task of the reproduction of the human species only. She has been looked down upon as a child-bearing machine. She has been facing humiliation, injustice, suppression, oppression, subjugation and exploitation in the world of males. She has always been a mute and silent sufferer totally dependent on her male counterpart.

An inevitable and unavoidable tragedy of the woman is that she is born and destined to passively, obediently and silently submit to the dreams, desires and aspirations of her male-counterpart. Her dreams, desires, aspirations, opinions, self and identity are suppressed in patriarchal set-up. She is identified and recognized in terms of her relationship with others. She is known as someone's daughter, someone's wife, someone's mother, someone's sister and someone's someone. In this connection, Indira Kulkshreshtha opines: "Generally, a woman's identity is defined in terms of her relationship with man as a daughter, a wife and a mother; it means virtually a woman doesn't have an identity of her own". (Kulkshreshtha 1987). She is not allowed to enjoy the status and dignity of being an individual who is equal to a man. She sees herself in her husband's shadow, lives as her husband wants her to leave, and behaves as her husband wants her to behave. She sheds her 'I' into her husband's. She gives up her name, self, virginity, almost everything in marriage. She becomes his ardhangini. She follows her husband willingly and ungrudgingly. She accepts her husband as a sheltering tree. She feels proud in doing these things. Though, she suffers a lot on account of the male-ego and male-domination, she considers herself incomplete, almost nothing without her husband. We should salute her silence, endurance, tolerance and sacrifice.

The Hindu moral code, known as 'The Laws of Manu', denies the woman a separate and independent existence apart from that of her male-counterpart. These laws define and decide the place, position and status of the woman in her family and society. The age-old respect for these laws dictates her destiny. She can not enjoy the taste of freedom and independence. She is made to submit herself to the authority of a man: father, husband, brother or son. She is made to believe that she derives her status and dignity from her husband, and power from her son. Both her success and failure are measured in terms of her husband's success and failure. Her father is the first guardian-cum master of the woman. In the absence of her father, his role is performed by his son or his male relatives; and when she is married; her father's role and function naturally is transferred to her husband. In marriage, she is separated from the roots the family in which she was born, brought up and nurtured, and is automatically connected to her husband's family with its values and norms, customs and conventions. She becomes a connecting link between two families, her ancestral family and marital family.

Though we speak of the feminine world and the masculine world, we know that the woman has never constituted a closed and independent world of her own. She derives pleasure in rotating around the world of males. She becomes an integral part of the universe which is controlled and governed by males. She herself accepts that the world, on the whole, is masculine. Man always takes delight in keeping the woman in a state of dependence. He tries to have a complete hold and control upon her; he strives to shape and mould her to his desires and dreams. She too submits passively to his wills and desires. She sees herself and makes her choices and decisions not in accordance with her nature and temperament, but in accordance with that of her malecounterpart. In Indian society, over the years, the woman has been ruled over by men in one way or the other by 
using the laws of his world against her. She continues to face injustice, humiliation, torture, harassment, suppression, oppression, subjugation and exploitation in the name of gender-distinction and patriarchy.

According to Ram Ahuja, there were two schools of thought regarding the status of women in ancient India. One school described women as 'the equals of men' while the other maintained that they were looked down upon with hatred, contempt and disrespect. They were regarded as means and objects of satisfying the physical hunger of men. In Vedic and Post-Vedic India, women enjoyed a status of goddess and of 'Ardhangini', the supreme source of men's inspiration. They could enjoy complete freedom not only in selecting their mates but even in their marital lives. They could enjoy freedom even in the fields of economics and religion. They could actively participate in religious ceremonies and discussions. They were allowed to educate themselves. They did not have any separate political status. Widows, however, were not allowed to remarry.

The status of women, in the Pauranic period, suffered a setback. Ram Ahuja, in connection with the status of women during this period, writes: "In the social field, pre-puberty marriages came to be practised, widow remarriage was prohibited, husband was given the status of god for a woman, education was totally denied to women, custom of sati became increasingly prevalent, purdah system came into vogue and practice of polygamy came to be tolerated. In the economic field, a woman was totally denied a share in her husband's property, by maintaining that 'a wife and a slave cannot own property'. In the religious field, she was forbidden to offer sacrifices and prayers, practise penances and undertake pilgrimages". (Ahuja 94). In the Buddhist period, the status of women improved a little. Women occupied a distinctly superior place in the field of religion. According to Ram Ahuja, they had their own sangha which was guided by the same rules and regulations as those of the monks. The sangha opened to them new avenues of cultural activities and social services and ample opportunities in public life. In the social field, their status improved a little, but remained unchanged in the political and economic fields. (Ahuja 94).

India was first invaded by the Muslims in the eighth century. It experienced the second Muslim invasion in the eleventh century. From this period onwards, the breakdown of social institutions, the upsetting of traditional political structures, the migration of people and the economic depression in the country contributed to the total depression in Indian social life, especially in the life of women. Women completely lost their status, dignity and glory during the Muslim rule. They were cut off from the main stream of life. However, during the fifteenth century, the social and the religious life of Indian women improved a little. According to Ram Ahuja, the Bhakti movement, organized by Ramanujacharya, introduced certain positive changes in the social and religious life of women in India. The saints like Chaitanya, Nanak, Meera, Kabir, Ramdas, Tulsi and Tukaram fought for the rights of women. Women received religious and social freedom due to the efforts of these saints. They were encouraged to read religious books and to educate themselves. (Ahuja 95).

Indian society witnessed certain changes in its economic and social structures during the British rule in India. Ram Ahuja, in his book Indian Social System, has listed six factors which, according to him, are responsible for the positive change in the status of women in India. These are: industrialization, spread of education, weakening of the caste-system, social movements initiated by some enlightened leaders and social reformers, growth of women's organizations and enactment of social legislation. (Ahuja 96-100). Illiteracy among women, their economic dependence on men, religious prohibitions imposed on them, caste restrictions, lack of female leadership, callous and malignant attitude of males towards women are some of the causes responsible for the low status of women in India after independence. Hinduism which considered males superior to females, the caste-system which imposed many restrictions on women and the patriarchal joint family system which curbed women's individuality and freedom, contributed to the low status of women in Indian society. Patriarchy, itself, has been one of the major causes of the woman's oppression and exploitation. Male power is exerted directly or indirectly in domestic and social life in order to constrain the female. The social role assigned to women is that of serving the image of man. Women are required to shoulder all the domestic responsibilities and they are kept busy with cleaning, cooking, washing and child-bearing roles. They are given just the status of sex partners.

The Constitution of India guarantees equality to women in different fields of life. It makes the provision of equal opportunity and equal pay for the equal work for women in private as well as public sectors. It makes special provisions in favour of women and children, renounces practices derogatory to the status and dignity of women and allows for provisions for securing just and humane conditions of work for women both from the rural and the urban area. However, in spite of these provisions made in favour of women, they have been facing issues such as female infanticide, gender-discrimination, sexual harassment, marital-violence, dowry, childmarriage, malnutrition, preference for a male child and many more. Female birth rate in India is lower than that of the male. Ultrasound scans, though beneficial to the mother and her baby, have been misused as they can reveal the sex of the baby, allowing pregnant women to decide to abort female foetus and try again for a male child. This is perhaps the main reason for the change in the ratio of the male to the female children. The law forbidding women or their families from knowing the sex of the baby after an ultra-sound scan is widely ignored. The abuse and evil of the dowry tradition has been one of the reasons for sex-selective abortions and 
female infanticide in a contemporary India. Though the female literacy rate in India is slowly rising, it, too, is definitely lower than the male literacy rate. Compared to the boys, fewer girls are enrolled in schools, and many of them drop out in the course of education. In urban India, the girls are nearly at par with the boys in the field of education. However, in rural India, they are less educated than the boys.

The place of women in our society is a burning issue merely discussed by Indians. No special efforts have really been made to improve their status and dignity. Women have rarely been given liberty and the position equal to men in our society. Naturally, they have a strong desire to be free and liberal. They do not like to live within the four walls of the house. Therefore, they have started educating themselves; they have started competing with men by exhibiting their talent and potentiality in different fields of life including games, sports, media, education, literature, medicine, engineering, science and politics; they have started taking up jobs and earning. Their earnings are used to meet the family expenses and to raise the quality of life. They are working with men at different work places with equal competence. Owing to their sincerity, their performance at work places is better than that of their male-counterparts. However, a question remains: how many of them have the right to spend the money they earn the way they like? I think, very few. These working women are not relieved of the drudgery of their household activities.

There have been two different attitudes towards women: one that women are weak, meek, submissive, silent, passive, need to be protected, kept at home as a daughter, a wife or a mother; and the other that women are goddesses like Lakshmi, Durga and Saraswati, who must be worshipped. However, Indian women are neither of these two. They are caught in a kind of dilemma in Indian patriarchal set-up. It is true that women are better than and superior to men in many respects. They are more tolerant, more enduring, more compromising, more sincere, and emotionally stronger that their male-counterparts. Silence, endurance, tolerance and sacrifice are her divine virtues which make her bear her tragic lot. They adjust themselves with changing circumstances with ease and speed. Though delicate and soft as a lily, they have a heart, far stronger and bolder than that of a man. They are the supreme inspiration for man's onward march towards progress, an embodiment of love, pity and compassion. We should respect her virtues. We should try to improve their status. We should change the way we look at the females who form half of the population of our country. Only government-made laws cannot save them from their problems. The root cause of her tragedy is our patriarchal attitude to women, male-ego and male-domination. Women empowerment is impossible unless and until we change our attitude to women. Women, too, should change their attitude to themselves. The gender-oriented attitude is the only obstacle in the way of their development and empowerment.

Thinkers, social reformers, female activists and organizations, today, are united over the female issues and are struggling for the development and empowerment of women. Our national leaders, Mahatma Gandhi, Pandit Nehru, Dr. Rajendra Prasad, Mahatma Phule and others made serious and deliberate efforts towards liberation and empowerment of women. They fought for their equality, justice and upliftment. They stressed the need of giving them the status equal to men in different walks of life. Goonaratne rightly said: It was Mahatma Gandhiji who revolutionalized the social set-up by changing and transforming the woman's status in India. Gandhian thought, philosophy and actions gave a new definition to the woman as an individual, independent and capable of taking care of herself. (Goonrante 123). His open invitation to Indian women to participate in the freedom struggle against the British rule as equal partners of men brought women out of their conventional and traditional mode of behaviour pattern. There has been a growing awareness on the injustices and abuses the women are subjected to. This awareness among Indians can be attributed to the influence of the social reformers fighting for the cause of women and also of the feminist movements, both Indian and Western.

Indian women, today, have been striving to capture their place, status, dignity and individuality. Independent India has seen a woman as the prime-minister in the form of Late Smt. Indira Gandhi. It has also seen a woman as the president in the form of Mrs. Pratibha Patil. It has seen many women as ambassadors, speakers, ministers, chief-ministers, legislators, governors, scientists, engineers, doctors, magistrates and what not. Education, a source of personality development, has helped and encouraged them to cast-off their age-old inferiority complex and contribute to their nation-building. They have started stepping out of Indian patriarchy; they have started questioning and opposing the orthodox conventions and traditional practices which are in favour of men. They have started revolting against male-domination and gender-discrimination. They are marching forward with grace and dignity side by side with men in every walk of life. They are contributing significantly towards the building of modern India. They have realized their value and importance as a social being. They know that they are the nucleus of their family and society.

Though, there has been a remarkable change in the place and position of women in India, there is a great disparity between the constitutional position of Indian women and the bitter reality of their plight and predicament. They are facing issues and problems such as gender-discrimination, child-marriage, dowry, malnutrition, rape, marital-violence, humiliation, exploitation, economic dependence, ignorance, superstitions and slavery. Unfortunately, they are looked down upon with contempt. They are reduced to the status of a plaything and a machine, an automaton used to fulfil man's sexual desire. Mere provisions made for them in our 
Constitution cannot change the lot of Indian women. We need to have a radical change in our attitude, in our mental make-up and even in our social structure to serve the purpose. Women themselves must be prepared to be the agents of change and instruments of their liberation. They need to make themselves strong and confident and emerge as new women ready to fight their battle for equality, justice, liberty on their own. They need to help themselves. Their education, confidence, determination, self-awareness, self-realization, self-confidence and self-assertion can lead them towards their liberation, development and empowerment.

\section{REFERENCES}

[1] Ahuja, Ram Indian Social System. Jaipur and New Delhi; Rawat Publications, 2002.

[2] Benjamin, Jessica. The Bonds of Love: Psychoanalysis, Feminism and the Problem of Domination. Virago, London. 1990.

[3] Beauvoir, Simone de. The Second Sex. New Delhi; H. M. Parshley. (Trans. and ed.), Penguin Books Ltd, 1972

[4] Figes, Eva. Patriarchal Attitudes: Women in Society. London; Macmillan, 1986.

[5] Goonratne, Yasmine. 'Traditional Elements in the Fiction of Kamala Markandya, R.K.Narayana and Ruth Praver Jhabvala'. WLWE. Vol. 15, No.1, April. 1976.

[6] Kierkegaard. Quoted from Beauvoir, Simone de. The Second Sex. H. M. Parshley (Trans. and ed.). New Delhi; Penguin Books Ltd, 1976.

[7] Kulkshreshtha, Indira. That Long Silence: Women in the Novels of Shashi Deshpande. 1987.

[8] Paulo, Frier. Pedagogy of the Oppressed. Land; Pelican, 1983. 